ISSN 2078-5526.Вісник Львівського університету.Серія педагогічна.2018. Випуск 33.С.254-266 Visnyk of Lviv University. Series Pedagogics. 2018. Issue 33. P. 254-266

УДК 376.015.311-056.36-057.874

DOI: http://dx.doi.org/10.30970/vpe.2018.33.9981

\title{
THE DIAGNOSTICS OF SOCIALLY DISADVANTAGED PUPILS WITH LEARNING DIFFICULTIES - INCLUSIVE APPROACH
}

\author{
Viera Shylonova, Vladymyr Klein \\ Catholic University in Ružomberok \\ Hrabovská cesta 1/A, Ružomberok, Slovakia-034 01
}

The paper is focused on current problems of education of pupis with specific developmental learning difficulties in primary education and on detection of intelligence relation (the social disadvantage) and the occurrence of specific development learning difficulties among primary school pupils with the emphasis on inclusive approach in the diagnostics of socially disadvantage pupils with learning difficulties. Early diagnostics is considered of key importance and the starting poing for the solution of topical problems of pupils from socially disadvantage environs with the emphasis on pupils with specific learning difficulties

Key words: diagnostics, socially disadvantaged pupil, specific developmental learning difficulties, inclusive education.

1. Current assessment of pupils with special educational needs (with emphasis on specific developmental learning disabilities)

The current perception of diagnosing special educational needs (SCVP) and general guidance services reflects the changes that are visible in perceptions and access to these pupils in relation to integrative and inclusive tendencies. The trend is no longer focusing on what the pupil fails, but the emphasis is on the area in which the individual excels, what can be done about the next intervention. The view of him changes and he is perceived as a person with the potential for further development. (Zelinková, 2001, p. 16) characterizes the change in the perception of diagnostics as follows:

- from the constant perception of the individual to the emphasis on development;

- from tests and their interpretations to assess the current state and search for the way forward;

- from typology, classification, comparison to individual descriptions and perceptions of individuals in development;

- from questions what does not he know? where it fails? to questions what does he know well?, what else does he know?, how to organize next steps?, how to change the conditions for best performance?;

(C) Shylonova V., Klein V., 2018 
- from the segregation of individuals with disabilities to integration between the ordinary population;

- from a medical model to a bio-psycho-social understanding of health.

Schröder (2000) describes a new accent in diagnostics that deviates from "pedagogy of the deficit" and the solution to support the child through proper inclusion in the system of special education to focus on the personality of the child, which strengthens the interest in analyzing the environment in which the child lives. The aim is that primary aid is not dependent on specific educational institutions. Strnadová (2010, p. 152) states that the goal of diagnostics is not to "hitch" the pupil, but to find the area of specific needs and to try to fulfill it. Diagnosis from this point of view is not the end of the diagnosis process, but rather the start of the next path of the child that we accompany. In this context, the newly used concept of diagnostic (Förderdiagnostik), i.e. diagnosis that focuses on supporting activity, development, changing the current state to the better instead of diagnosing the condition and assigning the diagnosis. This is a time-consuming and personally demanding process that shows the paths of pedagogical intervention.

\section{Diagnostics of Intelligence - Under-intelligence}

In this part of our contribution, we will address the question of determining the level of intellectual abilities in pupils, which is, in our circumstances, a highly psychological issue. Vagnerova $(2005$, p. 36) says that intelligence can be measured through performance or behavior in a certain precisely defined situation. This is a test that has been designed to capture the level of ability that affects the success of a school or a professional. In general, intellectual capabilities can be divided into two basic categories (verbal) and non-verbal (spatial) (Vagnerova, 2005 , p. 40). Intelligence tests are designed to produce a normal distribution of population results, i.e. the most numerous group of individuals with average assumptions (see Fontana, 1997). The result of the examination then makes it possible to compare the performance of the child being examined with the standards of the standardization group and determine how it works among the peers. "The aim of the intelligence examination is not only to assess the overall level but also to capture the individual structure of partial competencies, including the advantages and shortcomings of the child" (Vagnerova Klegrova, 2008, p.64). Factor of development when it is necessary to count on the uneven, uninterrupted development of intellectual abilities in the child, which is generally the result of the influence of family and school environment, and is also the result of individually specific developmentally conditioned change. At the primary stage, some changes in the development trend may still be expected, but the result of the examination at later age should be considered more stable, another factor is the choice of the test method. The examination of intellectual abilities is carried out in our conditions by a psychologist who should choose the most appropriate test, always with regards to the cultural environment from which the child comes from. Another factor is the 
ISSN 2078-5526. Вісник Львівського університету. Серія педагогічна. 2018. Випуск 33

choice of the criterion in the context of which the performance of the child is judged - in our case it is school achievement. It can be concluded that the predictive ability of intelligence tests is satisfactory in this regard (Vagnerova Klegrova, 2008, pp. 65-72).

\section{Diagnostics in the context of inclusive education}

Diagnosis is, among other things, a fundamental and integral part of the cycle of education and training. It is the way in which teachers identify the pupils' level of knowledge and when they are ready to receive new information. Inclusive perception of pedagogical diagnostics places demands on the diagnostic capability of a pedagogue as one of its professional competencies. In this context, we are experiencing a new approach to diagnostics, dynamic diagnostics. It is an an approach linking the elements of diagnostics and intervention. The aim is to get answers to questions such as cognitive skills, pupil metacognitive skills, pupil influence on the learning process, affective and motivational factors, how the pupil responds to the intervention and how we can help the pupil to make the learning process more efficient "(Hajkova, Strnadova, 2010, p. 11). Such an approach is currently being promoted not only in pedagogical work but also in the field of professional diagnostics in educational counseling and prevention facilities. Zelinkova (2007, p. 12) defines pedagogical diagnosis as a complex process whose aim is to identify, evaluate and evaluate the educational process and its actors. It focuses on content and process components. In addition to the level of knowledge and skills, she finds the emotional-social level of pupils. It also includes the diagnostics of the teacher's work, the methodologies used. "Diagnosis in inclusive viewing is an important tool for pupils, parents and teachers to reveal the strengths of the child, providing opportunities for future direction in the pupil's work. In our opinion, diagnosis in an inclusive environment should serve primarily as a tool for teachers to recognize specific and individually ongoing learning processes and learning conditions of a diagnosed pupil. Teacher is an absolutely indispensable diagnosis of the internal conditions of classroom education. Teacher and special pedagogue should monitor the pupil's success in terms of the diagnosis performed and the conditions with which the school can contribute to its success. As part of the diagnostic process, the school has an important position. Based on this, we consider inclusive diagnosis as a long-term process whose findings need to be consulted with other pupil observers (pedagogues, parents, counselors). This procedure can not be done routinely, impersonally and schematically, the conclusions drawn must be associated with suggestions for specific measures for the pupil's teaching activities, compensatory and reeducational procedures that go beyond the normal activities of the pedagogue (Hajkova, Strnadova, 2010, p.). Diagnosis and interactivity can also be considered as important elements of inclusive diagnostics. This is that the diagnose pupil is more perceived as a partner and an active participant, not only as a subject of observation, respecting its 
individuality. The interactive element is related to the recognition that inclusive diagnosis does not take place without the participants' social contact with each other, and cooperation is the most effective form of stimulus and information exchange. This can be understood either as a mutual stimulation of the participants in the diagnostic process, or as a method of interdisciplinary collaboration in determining the diagnosis. Hajkova and Strnadova (2010, p. 154) present four basic approaches to diagnosing special educational needs. It is focused on:

- pupil;

- an educational program;

- the area of potential development;

- learning environment.

The teacher needs information about the individual's progress in achieving the goals set. To do so, with regard to diagnostic and educational purposes, we recommend a measure-oriented and curriculum-oriented measurement. Measurement related to the curriculum relates to the objectives of the curriculum itself. The results can be used to compare the pupil's specific progress recorded e.g. in the form of a graph. Because such a measurement method is not designed to compare the pupil with other pupils in a class, we can consider it as a formatting assessment. Its advantage is that:

- it can be done by the teacher himself;

- it relates directly to the learning curriculum;

- acquires relatively objective data;

- can be performed relatively often;

- it relates to the objectives of education;

- the results assess the effectiveness of the teaching itself;

- allow for possible comparisons between groups (Biermann, Engelhardt, Goetze, 2005, pp. 28-36).

Based on objective information about pupil performance, the teacher is more likely to adapt the lesson in case of learning difficulties. Under these conditions, pupils are able to make much greater progress. From the point of view of diagnostic methods, inclusive diagnostics apply those that can be used in pupil's natural conditions and which emphasize the developmental aspect. There is definitely an observation, interview, anamnesis, well-designed tests and questionnaires - a significant part is devoted to the analysis of pupil's performance. An important role of the pupil's portfolio is defined as "... a set of different pupil's products (style works, dictates, drawings, pictorial material, writings, etc.) documenting his work as a pedagogical dictionary (Průcha, Walterova, Mareš, 2003)". An integral part of inclusive diagnostics is the diagnosis of classroom relationships, diagnosis of pupil behavior and work with his / her family.

4. The relation of general intelligence, specific developmental learning disabilities and socially disadvantaged environment 
The term also includes conditions such as perceptual deficiencies, brain injuries, mild brain dysfunctions, dyslexia and developmental aphasia. At present, we have the potential to predict potentially specific developmental learning disabilities even in pre-school children. According to Pokorna (2010, p. 19), the most critical is the discriminative model (the disagreement model), according to which the learning disabilities are diagnosed when the reading performance is lower than the intellectual performance expressed by the IQ value. Interestingly, Reschly and Grimas (1990, p. 427) claim that clinical psychologists use intelligence tests without considering the results of a diagnosis in each individual case. They point out the existence of "recognizable boundaries of intellectual measurement in creating education programs and other interventions for the benefit of learners and lost opportunities for the use of other potentially more efficient services that would match the time and energy involved in measuring intelligence". Simply put, "The time spent on the examination intelligence can be more usefully used by psychologists to analyze cognitive skills of an individual". Shinn (1989) recommends finding out how to improve pupil performance and analyze each of his achievements. Everyone in a subject who is significantly lagging should receive special educational care. Siegel $(1999$, p. 163) does not recommend to investigate intellectual performances using classical methods. In order to diagnose specific developmental learning disabilities, it is most important to find out what performances an individual achieves or attains at school, assessing reading performance, mathematics, and above all evaluating reading comprehension, understanding the meaning of the word, understanding mathematical operations and examining short-term memory. The author states that: “... I will advocate that IQ scores are irrelevant to identifying learning disabilities and that testing does not contribute to understanding the individual's educational needs". He believes there is only one reason why IQ is measured, that requires a definition. Shinn (1989) recommends finding out how to improve pupil performance and analyze each of his achievements. Everyone in a subject who is significantly lagging should receive special educational care. Siegel $(1999$, p. 163) does not recommend to investigate intellectual performances using classical methods. In order to diagnose specific developmental learning disabilities, it is most important to find out what performances an individual achieves or attains at school, assessing reading performance, mathematics, and above all evaluating reading comprehension, understanding the meaning of the word, understanding mathematical operations and examining short-term memory. The author states that: “... I will advocate that IQ scores are irrelevant to identifying learning disabilities and that testing does not contribute to understanding the individual's educational needs". He believes there is only one reason why IQ is measured, that requires a definition. The magnitude or the power of the intellect are concepts that are taken from physical reality. We all know that this is one centimeter. Intelligence, however, is not a physical reality, but 
a construction. We can add that there is considerable controversy about the nature of intelligence and how to measure it (Sternberg 2002, p. 519 and others). Reading is not dependent on intelligence, but depends on the development of cognitive functions. General verbal intelligence is directly related to not understanding the text, not the ability to read. Therefore, individuals with higher intelligence performance at the same level of ability to read begin to understand the meaning of the reader rather. This is evidenced by the fact that for good and above readers (measured by reading speed), we can measure low values when examining their intelligence (individuals with an IQ of less than 80 points). The same experience was gained by Siegl $(1999$, p. 167). She worked with children, but her conclusions also apply to adults. based on the results of the IQ, they have divided them into three groups: individuals with above average, average and sub-average intellectual performances. They then compared them according to the results of examinations related to the examination of language, memory, writing and phonological tasks. She did not find any significant difference between these groups. Individuals, of course, were different in the results of individual examinations, i. they were different in perceptual performances, but they were not in relation to intellectual abilities. In the case of weak readers, they reach any IQ values, they appear to have significant difficulties in phonological processing, and have shortages in short-term memory and in the perception of syntax. Sternberg and Grigorenko (1999) further point out that the final differences in scores represent different facts at different locations of the continuum of intellectual performance. For example, the difference of 10 points between IQ scores means something different for individuals with above average and something else with sub-intellect. Scissors are opening with intelligence height. This is a fact that is not reflected in our professional literature. Special pedagogues and counseling psychologists are satisfied with the average reading performance of children above average. Sieglova (1999, p. 167) denies the claim that in the current literature there is a significant discrepancy between the verbal and the non-verbal part of the intelligence test for determining the diagnosis of learning disabilities. She found that the distribution of performance in individual subtests does not differ from the normal population in children with learning disabilities. Spear-Swerling (1999) recommends that we use another source, proving the intolerance of discrepant theory, because it does not reveal learning disabilities in individuals with lower intellectual performance. They are objectively very poorly read, but because their intellect is below average, but they are not mentally handicapped, they do not achieve a sufficient discrepancy that requires definition, and therefore they are not included in reeducation care. It is convinced, like many other authors, that a better indicator than the IQ value for determining learning disability is to understand the reading and listening content. In addition, individuals with above average IQ and average reading performance should be included in reeducation. They have also been diagnosed with problems in the 
phonological processing of information (Fletcher, Forman, 1994, pp. 185-200). Sternberg, from the position of one of the most respected psychologists, completely rejects an intellectual examination for the diagnosis of learning disorders. Together with Grigorenko they state: “... the conventional way in which learning defects are defined and identified - in terms of the difference between IQ and the ability to read - is and must be wrong" (Sternberg, Grigorenko, 1999, p. 43). (Sternberg, Grigorenko 1999, p. 44). We want to emphasize one of them, because we consider it important in relation to the topic of our contribution: “... even the performances achieved in the non-verbal tests do not have much noticeable value, assumes that non-verbal tests denote verbal intellect skills more than verbal tests whose abilities are more developed in our cultural environment". The argument of both authors is that: "... even in nonverbal tests, the instruction is verbal and the material has no relation to what can be applied in ordinary life". Conclusion The authors conclude with radical arguments that: .... IQ has no place in diagnosis of learning disabilities (Sternberg, Grigorenko 1999, p. 64). We agree with Pokorna's opinion (2010), which says that: “... on the one hand, we are undermining the difficulties of children with lower intelligence, and on the other, we justify ourselves with insufficient efforts to correct them. We have changed the cause of the investigation with its purpose. The individual who has come to trust as a client due to the difficulties in the school, and his problems are professionally required to resolve, leaves the refused because he does not meet criteria that do not relate to his disability". Sternberg and Grigorenko (1999, pp. 9-28) are based on various assumptions of learning disorders but agree on a common definition: "Learning disabilities represent an interaction between the individual and the environment and are thus influenced by the actual expectation". In Slovakia, according to our empirical experience (and according to, for example, Varholikova, 2014, p. 52), there is currently no completely clear guidance valid for the diagnostic process of specific developmental learning disabilities. Expert circles are discussing whether a normointel condition is required when diagnosing them. From the point of view of our contribution, we consider it important to draw attention to the relationship between general intelligence, specific developmental learning disabilities, and the social environment. When testing a child from a different cultural and linguistic environment, we should use tests that are of cultural relevance to him (Sternberg, 2001) but which we do not have in Slovakia. Based on our practical experience (in line with Dockala's opinion, 2014, pp. 6-29), we believe that the management of claims for pupils in the so - the border zone is learning at a regular primary school over their strengths. A child with a low IQ value, in accordance with current school legislation, can not be included among pupils with special educational needs. But if we find the cause of their low intellectual performance in a disadvantaged social environment or in specific developmental learning disabilities, they are entitled to a special-pedagogical approach also under current school regulations. 


\section{Conclusions and recommendations}

In the years 2014 and 2015, the authors of the contribution carried out extensive research focused on the analysis of the situation in the field of diagnosing specific developmental disorders of socially disadvantaged pupils at elementary school, which results are presented in the monograph: Šilonová, Viera - Klein, Vladimír: Education of socially disadvantaged pupils with specific developmental learning disorders. First Edition. Verbum - publishing house KU Ružomberok. 2015. 225 s. ISBN 978-80-561-0262-6. In this part of the paper we will inform the readers of the results and conclusions of the research.

\section{We selectively list the following:}

1st area: Diagnosis of specific developmental learning disabilities

We have found an increasing tendency for specific developmental learning disabilities. We explain the given state by the following two underlying causes. We see the first cause in a high proportion of pupils from a socially disadvantaged environment, as research was carried out in the district of Spišská Nová Ves, which belongs to districts with a high share of families from socially disadvantaged communities. The second reason is seen in the approach of pedagogical and professional staff of schools and counseling facilities. We point out that currently used diagnostic tools are more suitable for children and pupils from an intact environment and with an average and higher intelligence than for children and pupils from a socially disadvantaged environment and with under-intelligence. The research results also point to another current issue, namely the absence of family collaboration with school and counseling facilities. Synergic result of insufficient pedagogical diagnostics, indicated problems in the area of diagnostics of professional staff and lack of cooperation with the family is a relatively high number of unidentified pupils with specific developmental learning disabilities and their failure after transition to the second stage of elementary school. Dyslexy, dysgraphy and dyortography are most often diagnosed, but a combination of diagnoses is also common. These diagnoses are related to the fact that they are pupils from a socially disadvantaged and in a language environment.

2nd area: Diagnostics - Effective mechanisms for early diagnosis

Effective mechanisms in the field of early diagnosis of specific developmental learning disabilities are considered screening examinations of schooling in pre-school age children and diagnostics of schooling. The results of the research have shown that both mechanisms are used by specialist staff at the counseling centers. Another mechanism for early diagnosis is early pedagogical diagnostics at primary education level. Therefore, if primary teachers do not identify pupils with learning difficulties early and do not recommend their counseling center to specialist diagnostics, difficulties in learning will only occur after the pupil moves from primary to secondary education. One of the mechanisms is also to gather information about the pupil. The results of the research have 
shown that the specialist staff of the counseling facilities obtain information about the pupil primarily by his / her own activities. In Slovak primary schools there are not yet enough professional staff employed. It then depends only on the quality of pedagogical staff in the school, whether they are able to recognize the pupil's learning difficulties in a timely manner and recommend it for a professional examination.

3rd area: The occurrence of specific developmental learning disabilities in pupils with under-intelligence in relation to the socially disadvantaged environment.

In view of our intention to point out the problem of diagnosing specific developmental learning disabilities in undergraduate pupils from a socially disadvantaged environment, we have also put up a research question: Is there a relationship between under-intelligence intelligence and the occurrence of specific developmental learning disabilities in primary school pupils from a socially disadvantaged environment? On the basis of the research findings, we answer that the relationship exists. We found that in the case of pupils from a socially disadvantaged environment, specialist staff in the counseling centers are deciding on the diagnosis based on the intellectual abilities of these pupils. The more intelligent the abilities are, the more common the diagnoses are. Regarding the occurrence of diagnoses in underprivileged pupils from a socially disadvantaged environment, the most common diagnoses are: dyslexia, dysgraphia and dysortography. We also surveyed the clinical picture of underprivileged pupils from a socially disadvantaged environment. We found that it was determined in the opinion of professional staff of consultancy facilities in the social environment. These pupils are characterized by a reduced intellect and a low level of reading literacy. The results again point to the fact that diagnostic tools are only intended for pupils with average and higher intelligence.

4th area: Unfunded conditions at school - Need for a school special pedagogue

One of the current problems of educating pupils with specific developmental learning disabilities at elementary schools is also the unspoken conditions in schools. For these reasons, we have identified a research question: Is there a need for special pedagogy at elementary schools in relation to under-aged pupils with specific developmental learning disabilities? The results of the research have shown that the staff of the counseling facilities cooperate with the professional staff of the school, but only if they are employed in the school. From our application practice, there is a lack of school special pedagogues, as confirmed by the participants with whom we have structured interviews.

5th area: Family and School Collaboration and Counseling Facilities

The major area where problems are currently occurring is the co-operation of the family of undergraduate pupils from a socially disadvantaged environment. 
Expert staff of counseling facilities and school special education teachers at elementary schools consider family co-operation with the school to be of great importance.

6th area: A system of school counseling facilities in Slovakia

Based on the research results and our own practical experience, we find that the system of school counseling facilities in Slovakia is inadequate and efficient. In recent years there has been an uncontrollable increase in school counseling facilities, especially in eastern Slovakia. By 2008, 13 effective PPPs were in Eastern Slovakia, following the adoption of the Act of the National Council of the Slovak Republic no. 245/2008 is currently 74, of which 27 are private. The system is neat, ineffective. We propose to stop an increase in the number of counseling facilities (often few professionals) and to abolish the dual school counseling system in the future. By removing the centers of special pedagogical counseling and transferring their competencies to the centers of pedagogical and psychological counseling and prevention, a uniform functional and effective system of advisory educational facilities in the Slovak Republic would be created according to the principle of "one door" where parents could solve their children's problems at one workplace with high-quality staff of special pedagogues, psychologists and other specialists in the centers of pedagogical-psychological counseling and prevention. We assume that this model would prevent misconceptions in the field of specific developmental learning disabilities, especially among pupils from a socially disadvantaged environment, into the system of special education of special classes of elementary school, and would guarantee the implementation of quality redaction for those pupils who are already pupils of special schools (classes) with the possibility of their subsequent transfer to the classes of ordinary elementary schools.

\section{Conclusion}

In the post, we focused on the topic of Inclusive Approach in Diagnosing Socially Disadvantaged Pupils with Difficulties in Learning, which is perceived by the pedagogic as well as the general public as very important and concerns a large part of primary school pupils. From our point of view, it is little explored and requires more attention in both the theoretical and practical areas, in order to improve the processes of their education with an emphasis on the application of humanistic and inclusive tendencies in the school system of Slovakia. Our goal was to point out the possibilities of making pupils educated in a triangle more efficient: socially disadvantaged pupil - level of intelligence - specific developmental learning disorder. With such a look at the issue, we met in foreign and domestic literature only very singularly and marginally.

This post is published in the framework of KEGA implementation no. 032 KU-4/2016 Promoting inclusive education at the pre-primary and primary level of the school system with emphasis on socially disadvantaged groups. 
1. Biermann, A., Engelhardt, A. \& Goetze, H. (2005). Play therapy for students with mental retardation <Spieltherapeutisch orientierte Förderung an Schulen für Geistigbehinderte>. Heilpädagogische Forschung, 31 (1), 28 - 36.

2. Dočkal, V., Farkašová, E., Kundrátová, B., Špotáková, M. (2004). RR screening. Testová batéria na vylúčenie mentálnej retardácie 6-10 ročných detí. Príručka. Bratislava: ECO.

3. Dočkal, V. (2014). Meranie inteligencie. In Psychológia a patopsychológia diet’at’a, číslo 3. Výskumný ústav detskej psychológie a patopsychológie v Bratislave, s. 6-29. ISBN 978-80-970733-7-4.

4. Fontana, D. (1997). Psychologie ve školní praxi. Praha: Portál, 1997. 384 s. ISBN: 80-7178-063-4.

5. Hájková, V., Strnádová, I. (2010). Inkluzivní vzdelávaní. Praha: Grada Publishing, a.s. 2010. 224 s. ISBN 978-80-247-3070-7.

6. Hájková, V., Strnádová, I. (2010). Inkluzívní vzdelávaní. Teórie a praxe. Praha: Grada Publishing, 2010.224s. ISBN 978-247-3070-7.

7. Mand, J. (2008). Lese- und Rechtschreibförderung in Kita, Schule und in der Therapie: Entwicklungsmodelle, diagnostische Methoden, Förderkonzepte. Stuttgart: Kohlhammer, 2008. 188 s. ISBN 978-3-17-020092-0.

8. Pokorná, V. (2010). Vývojové poruchy učení v dětství a dospělosti. Praha. Portál, s.r.o, 2010. ISBN 978-80-7367-773-2.

9. Průcha, J., Walterová, E., Mareš, J. (2003). Pedagogický slovník. Praha: Portál, 2003. 322 s. ISBN 80-7178-772-8.

10. Reschly, D.J.-Grimas, J.P. (1990). Best practices in intellectual assessment. In: best Practices in School Psychology. Washington, D.C.: NASP.

11. Shinn, M. R. (Ed.). (1989). Curriculum-based measurement: Assessing special children. New York: Guilford, $241 \mathrm{pp}$.

12. Schröder, U. (2000). Lernbehindertenpädagogik. Grundlagen und Perspektiven sonderpädagogischer Lernhilfe. Stuttgart: Kohlhammer. 2000. 283 s. ISBN 978-3-17-015421-6.

13. Siegel, L.S. (1999). Learning Disabilities: The Roads We Have raveles and the Path to the Future. In: R. J. STERNBERG, L. SPEAR-SWERLING (Ed.). Perspectives on Learning Disabilities, Biological, Cognitive, Contextual. Colorado, Oxford: Westiew Press, s. $159-175$.

14. Sovák, M. (1986). Nárys speciální pedagogiky. Praha: SPN, 1986. 231 s. $14-072-86$.

15. Spear - Swerling, L. (1999). Can We Get There from Here? Learning disabilities and Future Education Policy. In: R. J. STERNBERG, L. SPEAR- 
ISSN 2078-5526. Вісник Львівського університету. Серія педагогічна. 2018. Випуск 33

SWERLING (Ed.). Perspectives on Learning Disabilities, Biological, Cognitive, Contextual. Colorado, Oxford: Westiew Press, s. 250 - 273.

16. Sternberg, R. J. (2002). Kognitívni psychologie. Praha: Portál. ISBN 80-7178-376-5.

17. Sternberg, R.J., Grigorenko, E.L. (1999). Our Labeled Children. What Every Parent and Teacher Needs to Know about Learning Disabilities. Cambridge. NY: Persus Books.

18. Sternberg, R. J. (2001). Úspěšná inteligence. Praha: Grada. ISBN 80247-0120-0.

19. Varholíková, J. (2014). Súčasné možnosti diagnostiky špecifických porúch učenia. In Psychológia a patopsychológia diet’at’a, číslo 3. Výskumný ústav detskej psychológie a patopsychológie v Bratislave, s. 52. ISBN 978-80-970733-74.

20. Vágnerová, M. (2005). Školní poradenská psychologie pro pedagogy. Praha: Karolinum, 2005. 430 s. ISBN 80-246-1074-4.

21. Vágnerová, M. - Klégrová, J. (2008). Poradenská psychologická diagnostika dětí a dospívajících. Praha: Karolinum, 2008. 538 s. ISBN 978-80-246$1538-7$.

22. Werning, R., Lütje-Klose, B. (2003). Einführung in die Lernbehindertenpädagogik. München: Ernst Reinhardt, 2003. 231 S. ISBN 3-82522391-4.

23. Zapletalová, J. a kol. (2006). Obligatorní diagnózy a obligatorní diagnostika v pedagogicko-psychologických poradnách. Praha: IPPP ČR, 2006. 107 s. ISBN 80-86856-29-1.

24. Zelinková, O. (2007). Pedagogická diagnostika a individuální vzdělávací program. Praha: Portál, 2007. 54 s. ISBN 978-80-367-326-0. 
ДІАГНОСТИКА СОЦІАЛЬНО НЕЗАХИЩЕНИХ УЧНІВ ІЗ ТРУДНОЩАМИ У НАВЧАННІ - ІНКЛЮЗИВНИЙ ПІДХІД

\title{
Вєра Шилонова, Владимир Клеін
}

\author{
Католищький університет у Ружомберку, \\ вул. Грабовська 1/A, Ружомберок, Словаччина-034 01
}

Стаття присвячена актуальним проблемам освіти учнів зі специфічними труднощами у навчанні у системі початкової освіти, ролі рівня інтелекту та соціальної вразливості у виникненні специфічних труднощів у навчанні серед учнів цієї категорії. У статті робиться акцент на важливості реалізації інклюзивного підходу до діагностування соціально вразливих учнів з труднощами у навчанні.

Діагностування, серед іншого, є фундаментальною і невід'ємною частиною циклу освіти i навчання. Розуміння педагогічної діагностування (вивчення) у контексті інклюзії ставить вимоги до діагностичних можливостей педагога як однієї 3 його професійних компетенцій. Сучасне бачення діагностування освітніх потреб та планування відповідних послуг, відображає зміни, які відбулися у сприйнятті таких учнів у світлі інтегративних та інклюзивних тенденцій. Ми більше не зосереджуємося на тому, що учню не вдається, але акцент робиться на сильні сторони індивіда, на які можна спиратися у процесі подальшого втручання. Погляд на учня 3 труднощами у навчанні змінюється, він сприймається як людина 3 потенціалом для подальшого розвитку. Розглянуто ранню діагностику, що має ключове значення і $\epsilon$ початком розв'язання актуальних проблем учнів 3 соціально неблагополучних середовищ зі специфічними труднощами у навчанні.

Загалом, у цій статті ми зосередили увагу на темі інклюзивного підходу у діагностуванні соціально вразливих учнів 3 труднощами у навчанні. 3 нашої точки зору, вона мало вивчена і потребує більшої уваги як у теоретичній, так і у практичній сферах, 3 метою вдосконалення процесів освіти таких дітей, 3 акцентом на застосування гуманістичних та інклюзивних підходів у шкільній системі Словаччини. Наша мета полягала в тому, щоб вказати на можливості підвищення рівня освіти учнів у трикутнику: соціально вразливий учень - рівень інтелекту специфічний розлад розвитку. Це питання потребує подальшого розгляду у сучасній вітчизняній та зарубіжній науковій літературі.

Ключові слова: діагностика, соціально вразливий учень, специфічні труднощі у навчанні, інклюзивна освіта. 